\title{
SURGICAL TREATMENT OUTCOME OF AMNIOTIC BAND SYNDROME (ABS) INVOLVING THE FINGER AND LEG WITH INFECTION OF A FOUR-MONTHS MALE CHILD: A CASE REPORT
}

\section{LUARAN TATALAKSANA OPERASI SINDROM AMNIOTIC BAND JARI TANGAN DAN TUNGKAI DENGAN INFEKSI PADA ANAK LAKI-LAKI USIA 4 BULAN: SEBUAH LAPORAN KASUS}

\author{
Hendra Cahya Kumara ${ }^{1}$, Pamudji Utomo ${ }^{1}$, Umar Kharisma Islami ${ }^{2}$, Adhitya Indra Pradhana ${ }^{2}$ \\ ${ }^{1}$ Staff of Orthopaedic\& Traumatology Faculty of Medicine Universitas Sebelas Maret Surakarta/ Dr. \\ Moewardi General Hospital / Prof. Dr. R. Soeharso Orthopaedic Hospital \\ ${ }^{2}$ Resident of Orthopaedic \& Traumatology Faculty of Medicine Universitas Sebelas Maret Surakarta/ \\ Dr. Moewardi General Hospital / Prof. Dr. R. Soeharso Orthopaedic Hospital \\ Corespondent : dr. Umar Kharisma. Email : dr.aris 37@yahoo.com
}

\begin{abstract}
Amniotic band syndrome is an uncommon congenital disorder without any genetic or hereditary predisposition factor. It involves fetal entrapment in strands of amniotic tissue and causes an array of deletions and deformations. The aim of this article was to report surgical treatment outcome of amniotic band syndrome finger and infected intrauterine leg amputation. A case of four months male child with complaint of incomplete formation and constricting band on his left leg was reported. On the stump of left leg initially there was a small lump. Over time the size of the stump grew bigger and infected wound appeared. Other deformities were constricting band on proximal phalanx of the middle finger of left hand, acrosyndactyly of first and second toe of right foot and congenital scrotalis hernia. We performed a release surgery of constriction ring band of proximal phalanx of the middle finger of left hand with z-plasty incision and below knee amputation for left leg. We followed up patient in one year after operation. The patient complained no pain and no sign of infection. Patient could walk normally and independently with good activity daily living. We concluded that procedure with zplasty incision had good result and avoided morbidity. Below knee amputation procedure and application of suitable prosthesis provided satisfying outcome on patient activity daily living and ambulation.
\end{abstract}

Key words: Amniotic band syndrome, intrauterine amputation, z-plasty, infectio

\section{ABSTRAK}

Sindrom amniotic band merupakan kelainan bawaan yang jarang terjadi dan tanpa adanya kecenderungan faktor genetik atau keturunan. Kelainan ini diakibatkan terlilitnya janin dalam untaian jaringan amnion dan menyebabkan berbagai jenis kehilangan dan kecacatan. Tujuan dari artikel ini adalah melaporkan luaran tatalaksana operasi sindrom amniotic band pada jari tangan dan amputasi pada tungkai yang terinfeksi intrauterine. Pasien adalah seorang anak laki-laki empat bulan dengan amputasi tungkai bawah kiri disertai constriction band pada bagian proksimal. Pada ujung tungkai bawah kiri didapatkan benjolan dengan ukuran minimal yang makin lama ukuran sisi distal menjadi lebih besar dan tampak luka dengan nanah. Kelainan bentuk lainnya adalah constricting band pada phalanx proksimal jari tengah tangan kiri, acrosyndactyly jari kaki pertama dan kedua kaki kanan serta congenital hernia skrotalis. Kami melakukan operasi release constriction ring band phalanx proximal jari tengah tangan kiri dengan irisan z-plasty dan below knee amputation tungkai kiri. Follow up pasien setelah operasi satu tahun. Tidak ada keluhan nyeri, tidak ada tanda infeksi, pasien dapat berjalan normal dan aktivitas sehari-hari dengan mandiri. Kesimpulan bahwa prosedur dengan irisan z-plasty memberikan hasil yang baik dan menghidari morbiditas pasien. Prosedur below knee amputation dan penggunaan prosthesis yang tepat memberikan hasil yang memuaskan pada aktivitas seharihari dan ambulasi pasien.

Kata kunci: Sindrome amniotic band, amputasi intrauterine, z-plasty, infeksi

How To Cite: Kumara, H., Utomo, P., Islami, U., \& Pradhana, A. (2020). SURGICAL TREATMENT OUTCOME OF AMNIOTIC BAND SYNDROME (ABS) INVOLVING THE FINGER AND LEG WITH INFECTION OF A FOUR-MONTHS MALE CHILD: A CASE REPORT. Biomedika, 12(2), 90-97 doi:https://doi.org/10.23917/biomedika.v12i2.10562

DOI: https://doi.org/10.23917/ biomedika.v12i2.10562 


\section{INTODUCTION}

Amniotic band syndrome is a genetic disorder that involves fetal entrapment of the amniotic tissue strand and causes various deletions and deformations. This disorder rarely occurs without genetic dissociation or heredity (Shetty et al., 2013). It is also known as Amniotic Deformity, Adhesions, Mutilations (ADAM) complex, amnion ruptur sequence, amniotic band sequence, Streeter's dysplasia, congenital constriction bands, congenital band syndrome, and pseudoainhum. This entrapments of fetal body parts by the intrauterine band in ADAM complex causes malformations by diminishing the blood supplies to the affected organs (Sharma et al., 2015).

Constriction band syndrome (CBS) and amniotic band sequence are the terms applied to a wide range of congenital anomalies, most typically limb and digital amputations and constriction rings which occur in association with fibrous bands. These classic CBS birth defects represent disruptions, and do not occur along the known lines of embryologic development. CBS is also characterized by major anomalies of the craniofacial region and body wall complex (Koskimies et al., 2015).
Two pathogenesis theories have been put forward. The first one is the exogenous theory, it proposes that the early partial rupture of the amniotic sac leads to fibrous bands; these fibrous bands float in the amniotic fluid and can encircle and entrap a part of the fetus. These act as constricting bands as the fetus grows, causing reduced blood circulation, which can lead to autoamputation of a digit or limb in utero. In some cases, it leads to necrosis that requires surgical amputation following birth. The second theory is endogenous theory that suggest the tissue vascular supply disturbance (Shetty et al., 2013).

Patterson developed a useful classification for the extent of banding : first is simple constriction ring, second is constriction ring with deformity of the distal part, third is constriction with fusion of distal parts (acrosyndactyly), and fourth is complete intrauterine amputation (Ho, 2014).

Pieces of amnion and other material can be found in the depth of some clefts encircling and strangulating the digits. After the initial trauma, the defect heals and resulting cleft may be superficial and involve only on skin and part of the subcutaneous tissue, or it may involve veins, nerves, and arteries. Fusions of bone and 
skin may develop. Neurologic deficits distal to these deep clefts may be severe. Occasionally, even the bone can be involved, and abnormalities of the tibia may occur in association with the band (Ho, 2014).

\section{CASE REPORT}

A four-months male child came with his mother to pediatric orthopaedic clinic with complaint of swollen amputation stump of left leg and constricting band on his leg (Figure 2). On the stump of left leg initially was a small lump. Over time the size of the stump got bigger than its first appearance, and wound with pus appeared. Other deformities were constricting band on proximal phalanx of middle finger of left hand (Figure 1), acrosyndactyly of first and second toes of right foot (Figure 9), and congenital scrotalis hernia since birth. There was no history of trauma before.

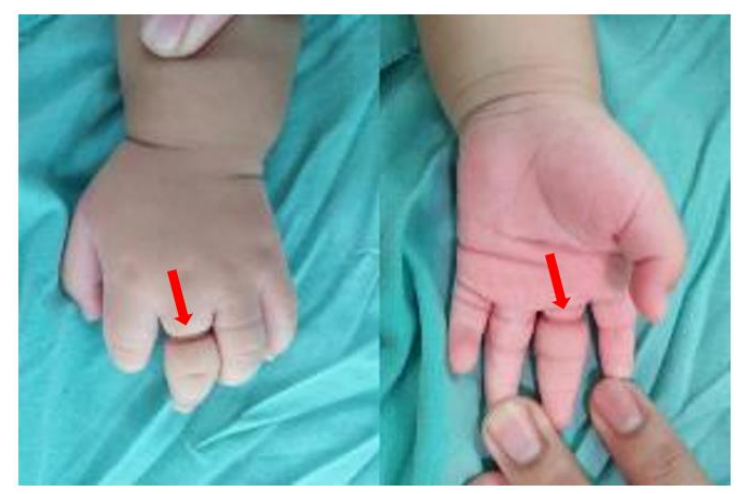

Figure 1. Constricting band on proximal phalanx of middle finger of left hand (red arrow)

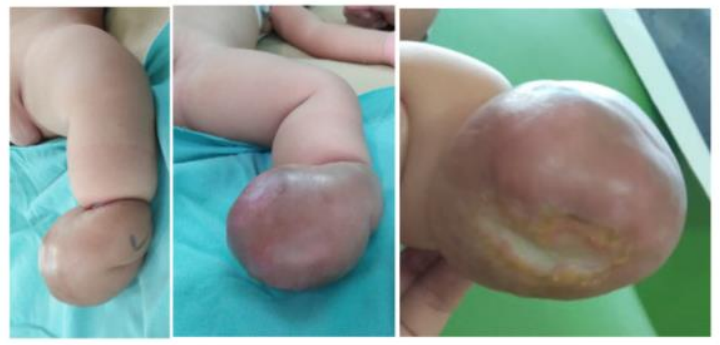

Figure 2. Amputation of left leg and constricting band.

Physical examination of the left hand showed constriction band on proximal phalanx of left hand with skin intact, redness, swelling, there was no neurovascular disturbance, CRT < 2 seconds, ROM of middle finger was limited. The left cruris showed amputated stump of left leg, swelling, redness, with wound size $2 \mathrm{~cm} \mathrm{x} 4$ $\mathrm{cm}$, irreguler border with pus. There was tenderness and we could not evaluate the neurovascular disturbance. X-ray of left hand $\mathrm{AP}$ and oblique showed normal bone structure of all digits. (Figure 3).

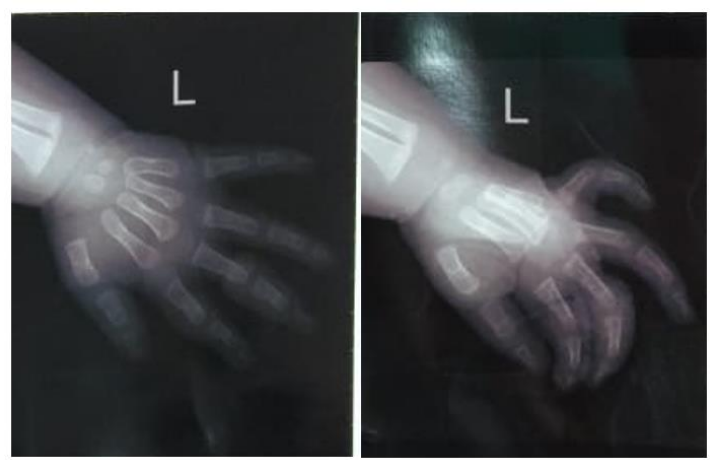

Figure 3. X-ray of left manus AP and oblique X-ray of left cruris AP lateral showed amputated tibia one third proximal and signs of soft tissue swelling in distal part (Figure. 4). 


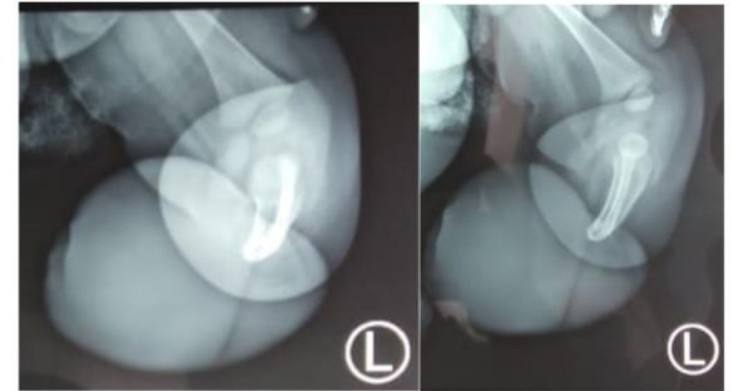

Figure 4. X-ray of left cruris AP and lateral

We diagnosed the patient with multiple anomaly, constriction ring band of proximal phalanx of middle finger of left hand, amputation of left leg, constriction ring band of left leg, acrosyndactyly of first and second toes of right foot and congenital scrotalis hernia. Surgery was performed for the orthopaedic problem.

We performed below knee amputation for left leg and a release surgery of constriction ring band of proximal phalanx of middle finger of left hand (Figure 5).

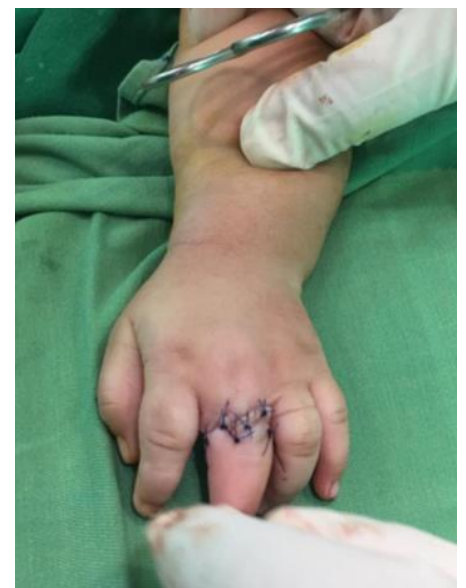

Figure 5. Release surgery of constriction ring band of proximal phalanx of middle finger of left hand.

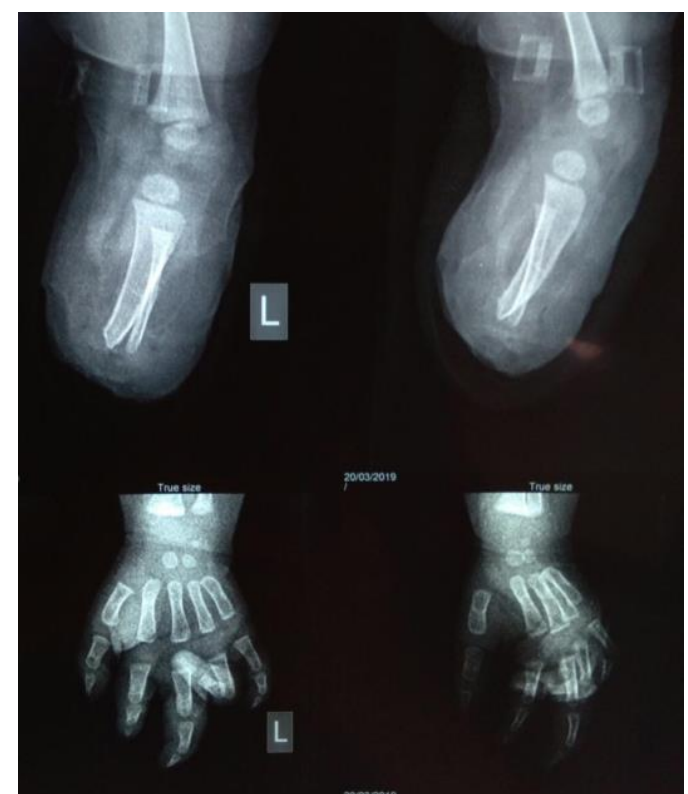

Figure 6. X-ray of left cruris AP lateral following amputation surgery and $\mathrm{x}$-ray of left manus AP and oblique after release surgery of constriction ring band of proximal phalanx of middle finger of left hand.

Patient's follow up after 1 month following operation revealed good outcome. The wound was healed, there was no pus and sign of infection. Three months follow up showed that the stump was in good condition and good shape which was suitable and ready for prosthesis fitting (Figure 7). The wound at proximal phalanx of middle finger of left hand was also in a good condition, viable, and well functioned (Figure 8). In twelve months follow up, the patient was able to walk and use his hand well, there was no complain or any restriction on his activity daily living (Figure 9). 


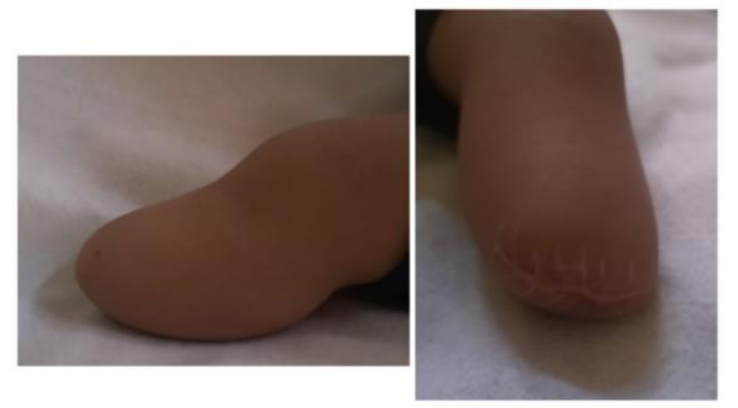

Figure 7. the clinical picture of one year follow up of the amputated stump.

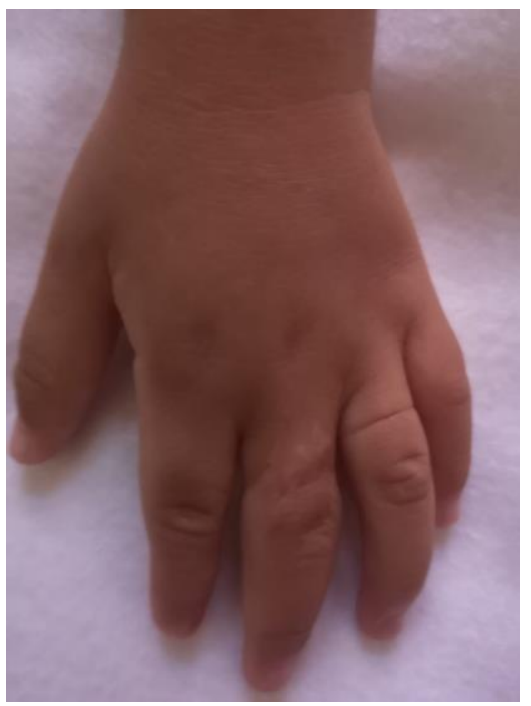

Figure 8. The clinical picture of one year follow up of left hand. There was the wound scar with good viability of middle finger.

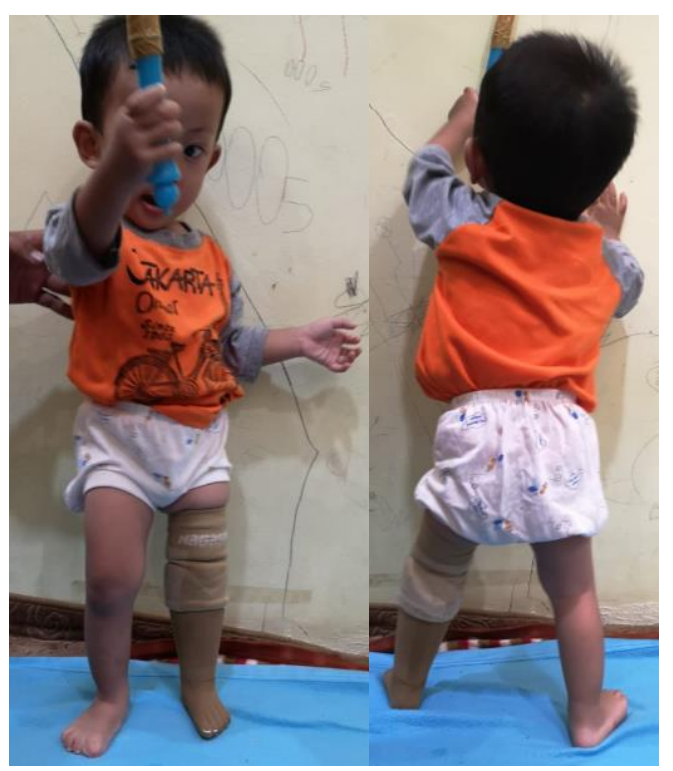

Figure 9. Follow up patient after one year, the patient stood using prosthetic of below knee patellar tendon bearing.

\section{DISCUSSION}

Amniotic band syndrome is a rare condition that can present with many clinical features, of which the major three components are circumferential transverse bands, acrosyndactyly, and terminal amputations (Weinstein and Flynn., 2014).

The international standard nomenclature for congenital limb deficiencies can help guide the initial assessment of Congenital Limb Deficiencies Disorders (CLLD) by dividing limb deficiencies into two types: longitudinal and transverse. In longitudinal deficiencies, there is a reduction or absence within the long axis of the limb and these deficiencies are often part of a more complex syndrome. Transverse limb deficiencies, as in this case, are defined as having a developmentally normal limb until a specific transverse plane is reached, with absent or dysmorphic limb features distal to that plane (Malone and Goodine, 2018).

Commonly, transverse limb deficiencies result from amniotic banding within the amniotic sac, which occurs when the amnion layer of the placenta ruptures and separates from the chorion, producing fibrous strands that entangle and compromise blood flow in affected extremities (Malone and Goodine, 2018). This 
patient's left hand, according to Patterson classification, is included in the first type, simple constriction ring. For the left leg, it is the fourth type in which complete intrauterine amputation occurs. The intrauterine constrictions are asymmetric with distal atrophy or amputation, pseudosyndactyly, lymphedema and clubfoot, in addition to severe craniofacial, visceral and trunk deformations (Herrera et al., 2018).

We perfomed a release surgery of congenital constriction bands because the limb or digit had vascular compromise. As well as in previous study (Ho, 2014; Weinstein and Flynn., 2014), the procedure should be performed through a dorsal incision releasing the band rather than a more aggressive Z-plasty or circumferential excision. Often the digit will not be salvageable; however, it will declare itself over time and definitive treatment (often amputation) can then be performed (Weinstein and Flynn, 2014). We performed amputation of left leg because the bone at the distal part of the leg were missing. As described in Weinstein and Flynn (2014), deep constriction bands that extend down to the deep fascia and sometimes beyond can cause vascular and neurologic compromise. The limb distal to the constriction can be very edematous due to the lymphedema and venous engorgement making vascular assessment difficult.

Orthopaedic management of ABS starts after birth and it is focused on decompression of nerves, vessels, and muscles as well as on improving their functioning and more acceptable esthetic appearance. Contemporary, the concept of a 1-staged removal of constrictions conducted as early as possible is widely accepted. Linear circumferential resection and closure rather than Z-plasties have been described as satisfactory in the literature. The release surgery will be safe on a condition that normal deep veins exist that can be decompressed by band removal. As already mentioned in Malone and Goodine (2018) there is no enlargement of edema after birth or extensive removal of the skin excess and softtissue masses from the deformed limb with ABS.

Amputation of a limb during childhood is a rare event that is consistently perceived as a catastrophe, first by the family and later on by the child. The principles required to create a stump capable of accepting a function-restoring prosthesis must therefore be fully understood. The patient must be managed by a 
multidisciplinary team of professionals who work closely together (Griffet, 2018). Prosthetic use in children with lower limb loss fulfils the appearance, provides early ambulation and adapts the child to home life and social participation through appropriate activity training (Ülger and Şener, 2011).

Children are special. Their rehabilitation requirements are different from those of an adult. Children's prostheses must allow some kind of growth adjustments. Children are extremely active, so the component used must be robust; at the same time, follow-up and repair services must be reliably available. Among the "soft factors" of treatment, the prosthesis as well as the fitting process must be enjoyable for the child to get the child to use the prosthesis. The objective of treatment here was achieved successfully, the child could fully reintegrate into his routine activity—schooling, cycling, and playing football. Only then we will be able to help the child to grow up without complexes and inhibitions into a happy individual (O'Keeffe and Rout, 2019).

\section{CONCLUSION}

Orthopaedic management of ABS starts after birth and it is focused on decompression of nerves, vessels, and muscles as well as on improving their functioning and more acceptable aesthetic appearance. We did an acute releasing surgery of congenital constriction bands with Z-plasty incision and have a good results, also we could avoid morbidity to the patient, provide more acceptable aesthetic appearance. We also performed below knee amputation procedure and applied prosthetic of below knee patellar tendon bearing. We achieved a good outcome in patient activity daily living and ambulation.

\section{REFFERENCES}

Griffet, J. 2016. Amputation and prosthesis fitting in paediatric patients. Orthop Traumatol Surg Res. 102(1):S161-75.

Herrera, H.R.J., Martínez, P.Y.M., and Izaguirre, E.D.M. 2015. Pseudosyndactyly and amputation as the main features of the amniotic band syndrome. Bol Med Hosp Infant Mex. 68(February 2009):50-2.

Ho, C. 2014. Tachdjian's Pediatric Orthopaedics. V. Herring JA, editor. United States of America: Texas Scottish Rite Hospital for Children.

Koskimies, E., Syvänen, J., Nietosvaara, Y., Mäkitie, O., and Pakkasjärvi, N. 2015. Congenital constriction band syndrome with limb defects. $J$ Pediatr Orthop. 35(1):100-3.

Malone, C., and Goodine, R.A. 2018. Constriction band syndrome in a healthy full-term newborn. Can Fam Physician. 64(8):577-8.

O'Keeffe, B., and Rout, S. 2019. Prosthetic rehabilitation in the lower limb. Indian $J$ Plast Surg. 52(1):134-44.

Shetty, P., Menezes, L.T., Tauro, L.F., and Diddigi, K.A. 2013. Amniotic Band Syndrome. Indian J Surg. 75(5):401-2. 
Sharma, D., Murki, S., and Pratap, O.T. Amniotic deformity, adhesions, mutilations (ADAM) complex: A frightful condition. Iran J Pediatr. 2015;25(1):4-5.

Ülger, Ö., and Şener, G. 2011. Functional outcome after prosthetic rehabilitation of children with acquired and congenital lower limb loss. J Pediatr Orthop Part B. 20(3):178-83.

Weinstein, S., and Flynn, J. 2014. Lovell and Winter's Pediatric Orthopaedics $7^{\text {th }}$ edition. Phliadelpia, USA.: Lippincott Williams \& Wilkins 